\title{
DISFUNGSI MIOKARD PADA SEPSIS DAN SYOK SEPTIK
}

\author{
Starry H. Rampengan \\ Bagian Ilmu Penyakit Jantung dan Pembuluh Darah \\ Fakultas Kedokteran Universitas Sam Ratulangi Manado \\ Email: starry8888@yahoo.com
}

\begin{abstract}
Sepsis and septic shock are serious clinical problems causing increased morbidity and mortality, which are highly associated with the event of myocardium dysfunction. Compared to previous data of four decades ago, there is an increase of mortality rate due to sepsis which is recorded based on the age from 0.5 to 7 per 100,000 sepsis episodes. The most common cause of sepsis is bacteria, which currently has shifted from negative to positive Gram bacteria. The most common organs affected by infection are lung (40\%), followed by abdomen (30\%) and urinary tract (10\%). Sepsis begins with an infection (nidus), which has to be present although finding the clinical evidence may be difficult or the evidence may not be found. Shock is a condition of inadequate blood flow to the tissues to maintain high-energy phosphates at the necessary level to keep normal cellular function. Patients with septic shock who did not survive were found to have progressive hypotension or being unresponsive and had multi-organ dysfunction. The most common effect of septic shock on cardiovascular system is defined by the characteristics of hemodynamic profiles including increased cardiac index and reduced systemic vascular resistance. Myocardium dysfunction is an important variable for sepsis and septic shock.
\end{abstract}

Keywords: myocardium dysfunction, sepsis, shock

\begin{abstract}
Abstrak: Sepsis dan syok septik merupakan masalah klinik serius yang banyak menyebabkan peningkatan morbiditas maupun mortalitas, yang erat kaitannya dengan kejadian disfungsi miokard. Dibandingkan dengan empat dekade yang lalu, tercatat angka mortalitas berdasarkan usia akibat sepsis meningkat dari 0,5 menjadi 7 per 100.000 episode sepsis. Sepsis paling sering disebabkan oleh bakteri yang saat ini penyebabnya telah bergeser dari bakteri Gram negatif ke bakteri Gram positif. Organ yang paling sering terjadi infeksi ialah paru (40\%) diikuti abdomen (30\%) dan traktus urinarius (10\%). Sepsis dimulai dengan infeksi (nidus) yang harus ada walau sulit dibuktikan secara klinis bahkan mungkin tidak dapat ditemukan. Syok adalah tidak cukupnya aliran darah jaringan dalam mempertahankan fosfat energi tinggi pada tingkat yang dibutuhkan untuk mempertahankan fungsi sel. Pasien syok septik yang tidak selamat didapati mengalami hipotensi progresif atau tidak responsif serta disfungsi multi organ. Efek syok septik yang tersering pada sistem kardiovaskular ialah karakteristik pada profil hemodinamik berupa peningkatan indeks jantung dan penurunan resistensi vaskular sistemik. Disfungsi miokard merupakan variabel penting pada sepsis dan syok septik.
\end{abstract}

Kata kunci: disfungsi miokard, sepsis, syok

Sepsis dan syok septik dikenal sebagai masalah klinik serius yang makin meningkat serta bertanggungjawab atas morbiditas dan mortalitas. Empat dekade yang lalu tercatat mortalitas berdasarkan usia akibat sepsis meningkat dari 0,5 menjadi 7 per 100.000 episode sepsis meskipun sudah terdapat kemajuan besar dalam pemahaman patofisiologinya. Insiden sepsis berat di Amerika Serikat saat ini diperkirakan sebanyak 750.000 kasus per tahun yang mengakibatkan 215.000 
kematian per tahun. ${ }^{1}$ Sebagian besar pasien sepsis meninggal akibat hipotensi refrakter dan kolaps kardiovaskular. ${ }^{1,2}$

Sepsis merupakan sindrom akibat respons inflamasi sistemik terhadap infeksi melalui pelepasan sitokin oleh makrofag berupa mediator proinflamasi dan antiinflamasi. Respons inflamasi yang terjadi tidak terkontrol sehingga timbul reaksi proinflamasi yang berlebihan. Keadaan ini memengaruhi langsung sel endotel, sistem kardiovaskular, mekanisme hemodinamik, dan koagulasi. ${ }^{1-3}$

Penyebab infeksi tersering pada sepsis ialah bakteri yang saat ini bergeser dari bakteri Gram negatif ke bakteri Gram positif. Penyebab lain ialah virus, jamur, dan parasit. Infeksi paling banyak terjadi di paru (40\%), diikuti abdomen (30\%) dan traktus urinarius (10\%). ${ }^{2,4}$

Bakteri yang menghasilkan endotoksin berinteraksi dengan monosit atau makrofag pada CD14 dan toll like receptor 4 (TLR4). Interaksi ini mengakibatkan pelepasan mediator peradangan lokal dan sistemik berupa sitokin oleh makrofag yaitu tumor necrosis factor- $\alpha$ (TNF- $\alpha$ ), interleukin-I $\beta$ (IL-I $\beta$ ), interleukin-6 (IL-6), interleukin-8 (IL-8), interferon- $\gamma$ (IFN- $\gamma$ ) (mediator kunci), dan mediator lainnya yaitu kinin, leukotrien, platelet activating factor (PAF), prostaglandin, dan nitrit oksida (NO). Sitokin-sitokin ini menstimulasi leukosit PMN, makrofag, dan sel endotel untuk melepaskan sejumlah mediator peradangan downstream, yang mencakup faktor pengaktifan platelet dan NO, yang selanjutnya memperkuat respons peradangan. Hal ini diikuti pembentukan mediator antiinflamasi yaitu transforming growth factor $\beta$ (TGF- $\beta$ ), IL-4, IL-10, IL11 , IL-13 dan antagonis reseptor IL-1.,3-6 Dukungan relatif dari sitokin-sitokin ini menentukan keparahan episode sepsis. Jika reaksi peradangan sangat kuat, homeostasis sistem kardiovaskular akan terganggu, sehingga mengakibatkan syok septik. Salah satu manifestasi disfungsi kardiovaskular pada syok septik ialah depresi miokard.,

Artikel ini membahas perubahan kardiovaskular, manifestasi klinik disfungsi jantung pada sepsis dan syok septik, dari sudut pandang ventrikel kiri dan ventrikel kanan, serta mekanisme dasar proses patofisiologi potensial yang bertanggungjawab atas terjadinya depresi miokard pada sepsis, dari perspektif fisiologi organ kardiovaskular dan biologi molekuler. ${ }^{8}$

\section{TERMINOLOGI DAN DEFINISI ${ }^{3}$}

Syok didefinisikan sebagai hipoperfusi jaringan, disertai hilangnya daya kompensasi sirkulasi akibat menurunnya resistensi perifer. ${ }^{1,2,9}$ Ditinjau aspek sirkulasi, syok merupakan kehilangan kemampuan kompensasi jantung dan pembuluh darah terhadap faktor pencetus syok. Pada sirkulasi terjadi kehilangan kemampuan kompensasi kontraksi sfingter arteriol akibatnya terjadinya vasodilatasi perifer sehingga menyebabkan darah terkumpul di perifer seperti dalam sebuah bejana; gejala ini disebut tank problem. Kehilangan daya vasokonstriksi arteriol terjadi disebabkan pengaruh pelbagai mediator. Walaupun sepsis menghasilkan tahanan vaskular sistemik yang rendah dan peningkatan curah jantung, bukti klinis kuat (penurunan fraksi ejeksi dan berkurangnya respons terhadap terapi cairan) mendukung bahwa miokard ventrikel mengalami depresi dan terjadi dilatasi ventrikel. ${ }^{1,8-10}$

\section{PATOGENESIS SEPSIS DAN SYOK SEPTIK}

Sel-sel yang bersirkulasi seperti makrofag, neutrofil dan platelet diikutsertakan pada daerah cedera atau terinfeksi serta sel-sel tersebut berhubungan dengan endotel dan memengaruhinya., ${ }^{81}$ Perubahan struktur, fungsi dan metabolisme sel endotel akan memengaruhi permeabilitas kapiler melalui produksi dan pelepasan mediator endogen yang berlebihan. ${ }^{11,12}$ Banyaknya sudut pandang mengenai mediator, patogenesis abnormalitas kardiovaskular, dan terapi sepsis membuat hal ini sulit dijelaskan dengan singkat. ${ }^{2,12}$ 
Sepsis dimulai dengan infeksi (nidus) yang harus ada walau sulit dibuktikan secara klinis bahkan tidak dapat ditemukan. $^{1,9,13}$ Substansi dinding sel, endotoksin pada bakteri mengaktifkan sistem komplemen, kinin, endorfin, dan monokin. ${ }^{1,8,14}$ Endotoksin merupakan komponen dinding sel normal bakteri, pada bakteri Gram positif dikenal sebagai asam lipotekoid dan pada bakteri Gram negatif disebut sebagai lipopolisakarida (LPS). ${ }^{7,15}$ Lipopolisakarida mempunyai 3 komponen yaitu rantai O-spesifik, inti dan lipid A. Lipid A merupakan bagian terpenting yang strukturnya selalu tetap pada berbagai jalur bakteri Gram negatif. Ikatan LPS atau protein imunogenik lain dengan neutrofil, makrofag, dan endotel vaskular mencetus pembentukan sejumlah lipid dan mediator kimia.,15,16 Mediator pejamu (host mediator) akan dilepaskan membentuk kaskade syok septik, disfungsi organ, dan gagal organ (Gambar 1).,17,18

Peningkatan insidens sepsis oleh bakteri Gram positif dan jamur memberikan kemungkinan peran faktor mediator lain seperti peptidoglikan dan asam lipotekoik. ${ }^{8}$ Proses ini merupakan mekanisme pertahanan tubuh untuk membatasi dan menetralkan mikroorganisme invasif, membuang sel-sel yang rusak, serta memperbaiki jaringan yang cedera. Aktivitas yang terjadi secara berlebihan akan merugikan. ${ }^{11,17}$ Secara umum syok septik merupakan ekspresi klinis respons pejamu yang berlebihan. ${ }^{18}$

Sistem kinin yang teraktivasi endoktosin atau kompleks antigen-antibodi menyebabkan peningkatan permeabilitas kapiler, vasodilatasi, peningkatan aktivitas fagosit, dan serangan langsung komplemen terhadap patogen tersebut. ${ }^{1,7,18}$ Fagosit terutama neutrofil melepaskan radikal bebas yang merusak jaringan dan endotel vaskular. $^{1,16}$ Disfungsi endotel turut memacu proses inflamasi dan meningkatkan permeabilitas kapiler. $^{7,16,19}$

Makrofag melepaskan mediator primer antara lain TNF- $\alpha$, IL- $1 \beta$, dan komplemen, sedangkan neutrofil melepaskan mediator primer lain seperti PAF. Secara langsung maupun tidak, pelepasan TNF- $\alpha$, IL- $1 \beta$, dan PAF akan mengakibatkan vasodilatasi dan peningkatan permeabilitas kapiler. ${ }^{7-}$ $9,20,21$

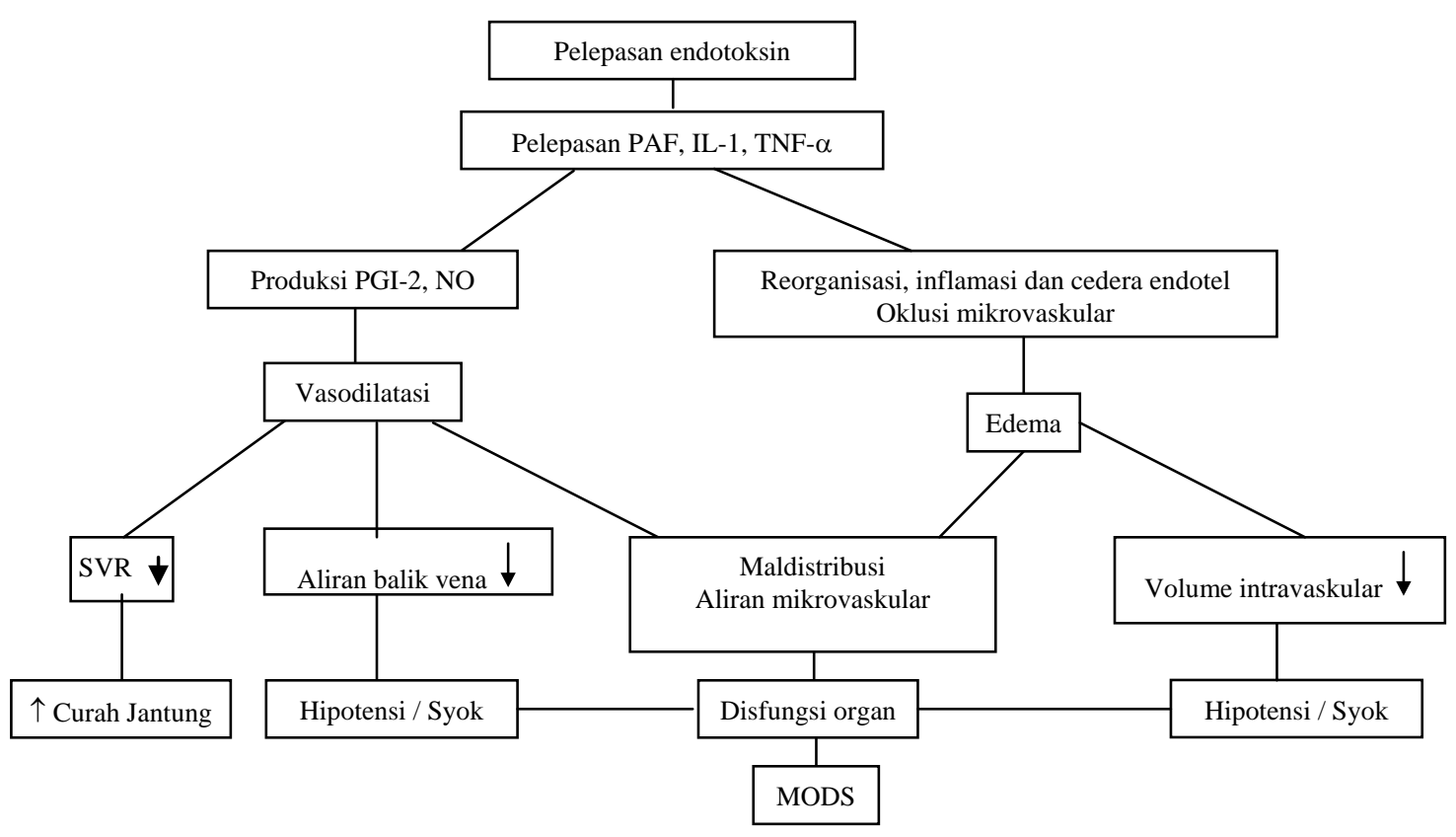

Gambar 1. Kaskade inflamasi sistemik/sepsis. Sumber: Deymann et al, 2002. ${ }^{6}$ MODS: Multiple organ dyfunction syndrome; SVR: Systemic vaskular resistence 
Respons sel terhadap TNF- $\alpha$, IL-1, atau PAF tergantung beberapa faktor seperti dosis yang diterima, jenis sel dan jaringan, serta sensitisasi sebelumnya. ${ }^{7}$ Berdasarkan informasi tersebut, Bone $^{8}$ menjelaskan patogenesis sepsis dan SIRS adalah peranan inflamasi menetap dan tidak terkontrol.

Dewasa ini diketahui mediator seperti IL-4, IL-10, IL-11, IL-13, dan colonystimulating factors, mempunyai soluble receptor terhadap TNF- $\alpha$ dan antagonis reseptor terhadap IL-1 $\beta$ dan berperan dalam respons anti-inflamasi. Beberapa mediator terutama interleukin, berefek terhadap fungsi monosit termasuk aktivitas presentasi antigen. Mediator tersebut juga menghambat aktivitas limfosit $\mathrm{T}$ dan $\mathrm{B}$. Peran mediator proinflamasi dan anti inflamasi serta responsnya memberikan pengertian yang dikenal sebagai compensatory anti-inflammatory respons syndrome (CARS), dan mixed antiinflammatory respons syndrome (MARS) (Gambar 2). ${ }^{8,12}$

Mekanisme patogenesis yang mendasari disfungsi kardiovaskular pada syok septik sangat kompleks. Syok adalah tidak cukupnya aliran darah jaringan dalam mempertahankan fosfat energi tinggi pada tingkat yang dibutuhkan untuk mempertahankan fungsi sel.,12 Hipoksia sel atau hipoksia jaringan merupakan faktor yang menentukan terjadinya syok. Pada syok septik didapati curah jantung normal atau tinggi sehingga mekanisme terjadinya syok menjadi perdebatan.

Terdapat beberapa hipotesis yang menjelaskan perbedaan ini termasuk pirau atau anastomosis arteri-vena, disfungsi mitokondria, dan maldistribusi aliran darah.,13 Vasodilatasi pada sepsis mempunyai potensi membuka anastomosis arteri vena dan menimbulkan pirau. Hal ini menyebabkan aliran darah rendah di jaringan meski curah jantung tinggi. Hipotesis ini tidak didukung penelitian eksperimental. Radiolabeled microspheres yang disuntikkan ke ventrikel kiri tidak terlihat pada sirkulasi vena. Hal tersebut menunjukkan terjadi penyaringan sempurna di kapiler. Hipotesis terjadinya hipoksia sel karena penggunaan oksigen yang abnormal kurang didukung oleh data-data akurat. Disebutkan bahwa endotoksin mempunyai efek difus terhadap sel dan hal tersebut menyebabkan disfungsi mitokondria pada pasien sepsis. $^{3,12,18}$

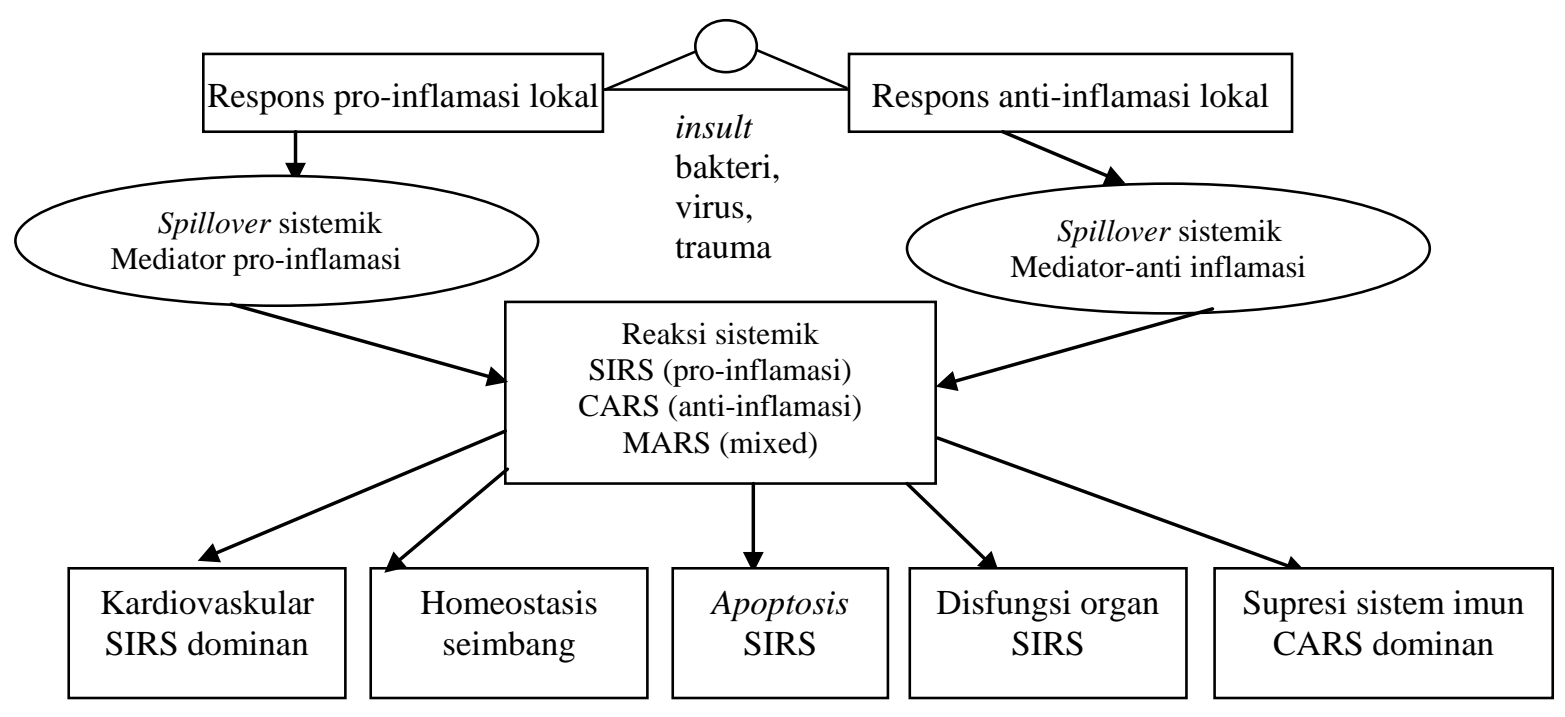

Gambar 2. Sekuele klinik dari SIRS,CARS, dan MARS. Sumber: Dellinger RP et al, 2013. ${ }^{3}$ 
Hipotesis terakhir yang diajukan ialah terjadi maldistribusi aliran darah pada organ ataupun intra-organ.,7,19 Maldistribusi aliran darah akan menye-babkan aliran yang tidak adekuat pada organ atau jaringan. Masih belum jelas bagaimana frekuensi timbulnya hipoperfusi jaringan pada curah jantung normal atau tinggi. Syok septik seringkali disalahartikan dengan hipotensi septik' pada kondisi tersebut tidak didapatkan hipoperfusi jaringan. Penelitian lebih lanjut mengenai hubungan penampilan jantung dengan petanda hipoperfusi jaringan memperjelas tentang proses hipoksia sel yang timbul pada kondisi curah jantung tinggi. ${ }^{3,20}$

Diagram skematik langkah-langkah sampai terjadinya abnormalitas kardiovaskular dimulai dengan sumber infeksi berupa abses, peritonitis, pneumonitis, sellulitis, dan sumber fokus lainnya. Mikroorganisme kemudian menginvasi masuk ke dalam aliran darah (sehingga hasil kultur darah positif), kemudian mikroorganisme berproliferasi pada sisi infeksi dan melepaskan sejumlah besar variasi mediator ke dalam aliran darah. Mediator-mediator ini terdiri dari eksotoksin elaborasi mikroorganisme, endotoksin komponen struktural mikro-organisme, antigen asam teikoid atau penjamu menghasilkan langsung seperti sitokin (TNF- $\alpha$, interleukin) maupun aktivasi komplemen. Walaupun beberapa mediator ini dipastikan lebih penting dari yang lain, namun didapati 20-30 substansi molekul yang memengaruhi secara mendalam pembuluh darah paru dan perifer, dan beberapa substansi (seperti substansi depresan miokard, dll) memperlihatkan efek langsung terhadap miokard itu sendiri. 5,7,16,19

Kombinasi abnormalitas pembuluh darah dan miokard secara umum akan menyebabkan insufisiensi kardiovaskular. Pasien syok septik yang tidak selamat didapati mengalami hipotensi progresif atau tidak responsif serta multiorgan disfungsi. Hipotensi tidak responsif disebabkan karena sangat rendahnya resistensi vaskular sistemik yang tidak dapat dikoreksi dengan terapi apapun. Hanya sejumlah kecil $(<10 \%)$ hipotensi tidak responsif yang disebabkan oleh curah jantung rendah (dekompensasi depresi miokard). Disfungsi multipel organ berefek langsung pada ginjal, hati, sistem saraf pusat, jantung, paru, dan kematian disebabkan karena gagalnya satu dari beberapa sistem organ tersebut (Gambar 3). ${ }^{16,18,21}$

\section{KARAKTERISTIK FUNGSI JAN- TUNG DALAM SYOK SEPTIK}

Penurunan tahapan vaskular sistemik karena vasodilatasi arteri, peningkatan curah jantung, penurunan kontraktilitas miokard, peningkatan volume ventrikel, dan perubahan respons ventrikel terhadap rangsangan simpatis serta respons ventrikel terhadap pemberian cairan merupakan perubahan hemodinamik yang terjadi pada sepsis. ${ }^{2,3,9,18,22}$ Laju irama jantung meningkat dan tahanan vaskular paru sedikit meningkat. ${ }^{3,16}$ Secara umum pada sepsis ditemukan maldistribusi dan penurunan aliran darah kapiler yang mengakibatkan ketidakcukupan gradien untuk perfusi oksigen sehingga menyebabkan hipoksemia sel. Terdapat maldistribusi menyeluruh aliran darah pada hampir semua pasien dengan syok septik. 3,7,9,21 Perubahan hemodinamik pada syok septik berbeda dengan syok karena sebab lain.,10 Gambaran hemodinamik klasik syok septik pada manusia ialah hipotensi karena vasodilatasi arteri sehingga tahanan vaskular sistemik sangat rendah dengan curah jantung yang tinggi. ${ }^{1-3,7,11,23}$ Setelah pemberian cairan yang agresif untuk mendapatkan beban awal yang optimal, didapatkan curah jantung awal yang normal atau tinggi pada $80 \%$ kasus. ${ }^{9,21,23}$

\section{Vasodilatasi arteri}

Vasodilatasi arteri patologik merupakan defek hemodinamik terpenting pada sepsis. Vasodilatasi arteri terjadi karena hilangnya tonus otot polos pembuluh darah. $3,7,21,24$ 


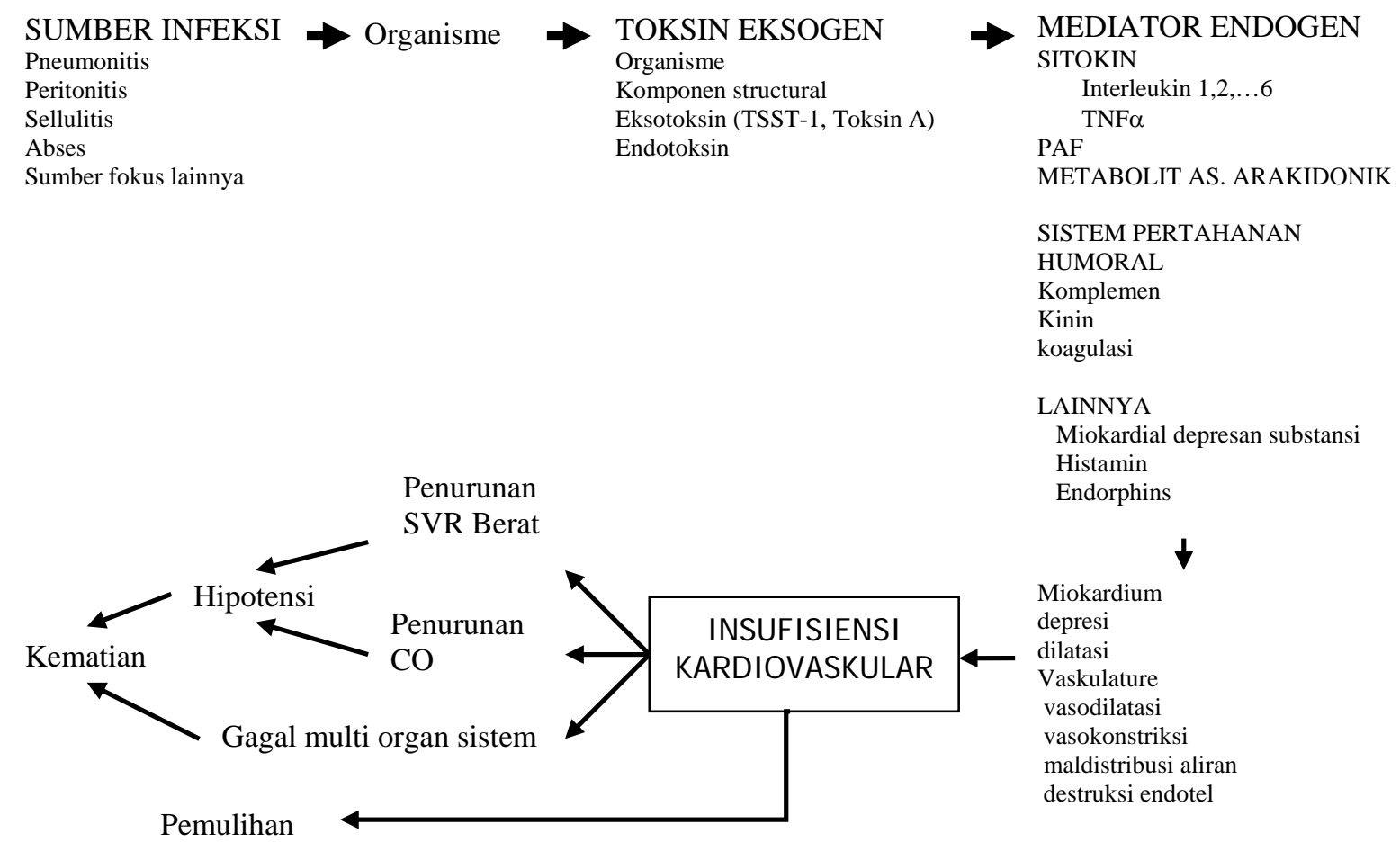

Gambar 3. Patogenesis langkah dari sumber infeksi sampai disfungsi kardiovaskular dan syok selama sepsis pada manusia. Sumber: Dellinger RP et al, $2013 .^{3}$

"SVR=systemic vaskular resistance, $\mathrm{CO}=$ cardiac output, $\mathrm{MOSF}=$ multi organ system failure

Vasodilatasi akan menurunkan tahanan pembuluh darah sistemik yang menyebabkan disregulasi aliran darah mikrovaskular dan penurunan arus balik vena. Disregulasi mikrovaskular dapat menyebabkan terbentuknya pirau intraorgan. 1,3,23,25 Konsekuensi fisiologik vasodilatasi ialah peningkatan curah jantung, gangguan perfusi jaringan, penurunan volume darah efektif, takikardi dan hipotensi. Dua faktor yang berinteraksi dan menyebabkan vasodilatasi ialah hilangnya sifat responsif pembuluh darah terhadap stimulasi simpatik dan peningkatan produksi substansi endotel yang mengakibatkan relaksasi otot polos pembuluh darah (endothelial derived relaxing factors /EDRF). 1,3,7,21,23

\section{Hilangnya sifat responsif pembuluh darah terhadap stimulasi simpatik}

Pada keadaan normal norepinefrin dan epinefrin mempertahankan tonus pembuluh darah melalui reseptor adrenergik $\alpha$ dan $\beta$ di otot polos pembuluh darah. Pada syok septik diperlukan epenefrin atau norepinefrin atau keduanya dalam dosis tinggi untuk mempertahankan tekanan darah yang cukup. ${ }^{7,23,24}$ Resistensi terhadap adrenergik ini ${ }^{7}$ disebabkan 3 hal:

1 Gangguan sel reseptor yang menyebabkan afinitasnya menurun

2 Sel vaskular menurunkan jumlah reseptor adrenergik yang merupakan respons terhadap TNF- $\alpha$

3 Defek intrasel yang tercetus mungkin menghambat kemampuan sel menerima sinyal walaupun epinefrin dan norepinefrin terikat dengan baik pada reseptornya

Keadaan ini dapat menerangkan syok septik yang refrakter terhadap epinefrin dan norepinefrin dosis tinggi. $3,7,21,23-25$

\section{Vasodilatasi yang disebabkan EDRF}

Respons inflamasi terhadap sejumlah substansi (seperti bradikinin, histamin) menyebabkan terjadi peningkatan produksi substansi endotel yang mengakibatkan 
relaksasi otot polos pembuluh darah secara keseluruhan dan menurunkan tonus vaskular. ${ }^{2,16,21,25}$ Sebagai respons terhadap PAF, TNF- $\alpha$ atau IL-1 $\beta$, sel endotel menghasilkan 2 vasodilator kuat dalam jumlah besar yaitu Prostaglandin $\mathrm{I}_{2}\left(\mathrm{PGI}_{2}\right)$ dan NO., ${ }^{3,721,26}$ Pada keadaan normal $\mathrm{PGl}_{2}$ atau yang disebut prostasiklin diproduksi dalam jumlah kecil oleh sel endotel pembuluh darah untuk mengimbangi vasokonstriksi yang disebabkan oleh substansi adrenegrik. Pada sepsis, mediator PAF, TNF- $\alpha$ dan IL-1 $\beta$ meningkatkan aktivitas enzim sel yang berperan dalam pembentukan $\mathrm{PGl}_{2}$, prostaglandin lain, serta mediator asam lemak lain seperti tromboksan dan leukotrien. Enzim fosfolipase A2 melepaskan sejumlah asam arakidonat yang akan dimetabolisme oleh sel endotel menjadi $\mathrm{PGl}_{2}$, sehingga $\mathrm{PGl}_{2}$ akan diproduksi dalam jumlah besar dan menyebabkan relaksasi sel otot polos pembuluh darah. ${ }^{7,13,25}$ Nitrid oksida diproduksi dari asam amino L-Arginine oleh sel endotel. ${ }^{7,21,22}$ Pada keadaan normal NO dilepaskan dalam jangka pendek untuk menyeimbangkan keadaan vasokonstriksi. ${ }^{7}$ Dua jenis enzim intrasel yang memproduksi nitric oxide syntethase telah berhasil diidentifikasi. ${ }^{7,21,22}$ Enzim pertama (cNOS) sensitif terhadap peningkatan kadar kalsium intrasel dan terdapat sepanjang endotel, endokard, maupun miokard. Konsentrasi dalam sel tetap sehingga selalu mempunyai pengaruh terhadap jumlah total NO yang dihasilkan pada syok septik. Sebagai respons terhadap PAF, TNF- $\alpha$, dan IL-1 $\beta$ maka makrofag, neutrofil, sel otot polos pembuluh darah dan sel endotel membentuk enzim kedua yang juga menghasilkan NO (iNOS).,21,26 Sekali terbentuk, enzim ini akan mampu berproduksi selama 24-48 jam. Jika memperhitungkan jumlah sel endotel melalui masa tubuh total, pembentukan NO jumlah besar mungkin terjadi. NO menyebabkan relaksasi otot polos pembuluh darah, menurunkan tekanan darah, menimbulkan gangguan aliran darah mikrovaskular, serta menurunkan beban awal dan beban akhir. ${ }^{7,21}$ Cedera dan kerusakan endotel vaskular di sistem paru, jantung, dan ginjal akan meningkatkan terjadinya Aadult Respiratory Distress Syndrome (ARDS), depresi miokard, dan gagal ginjal akut. ${ }^{7,13}$ Terjadinya edema pada syok septik disebabkan oleh 3 hal, yaitu: integritas endotel terganggu, cedera endotel, dan oklusi mikrovaskular. ${ }^{7,21,26,28}$

Pada syok septik terjadi respons tubuh terhadap inflamasi sistemik dan infeksi sehingga mengakibatkan vasodilatasi perifer. Respons klasik kardiovaskular terhadap syok septik ialah vasodilatasi perifer yang bermanifestasi sebagai hipotensi sistemik, walaupun respons ini sebenarnya kurang dapat menekan agen penyebab sepsis.

Radionuklid, gated blood-pool scanning dan hemodinamik termodilusi digunakan untuk mempelajari kerja ventrikel dan volume ventrikel secara serial sesudah onset dari syok septik. Pengukuran radionuklid sebagai faktor yang menentukan ejeksi fraksi ventrikel kiri terbukti sebagai pengukuran fungsi ventrikel yang sangat berguna pada penyakit ini. Fraksi ejeksi relatif tidak berubah oleh perubahan akut preload dan afterload. Pada fase permulaan studi follow up contoh karakteristik syok septik termasuk penurunan awal ejeksi fraksi terjadi dalam 24 jam pertama onset syok septik (Gambar 4). Hubungan dengan penyakit ini adalah terjadi peningkatan volume akhir diastolik dan akhir sistolik. Penurunan ejeksi fraksi dan dilatasi ventrikel didapati sebagai karakteristik tersering pasien syok septik yang selamat selama beberapa hari fase awal penyakit (depresi miokard terkompensasi). Salah satu karakteristik yang terpenting dari bentuk ini adalah reversibiliti. Pada grup yang selamat, fungsi dan ukuran ventrikel kembali normal dalam 7-10 hari sesudah onset dari syok septik. ${ }^{7,21,27}$ 


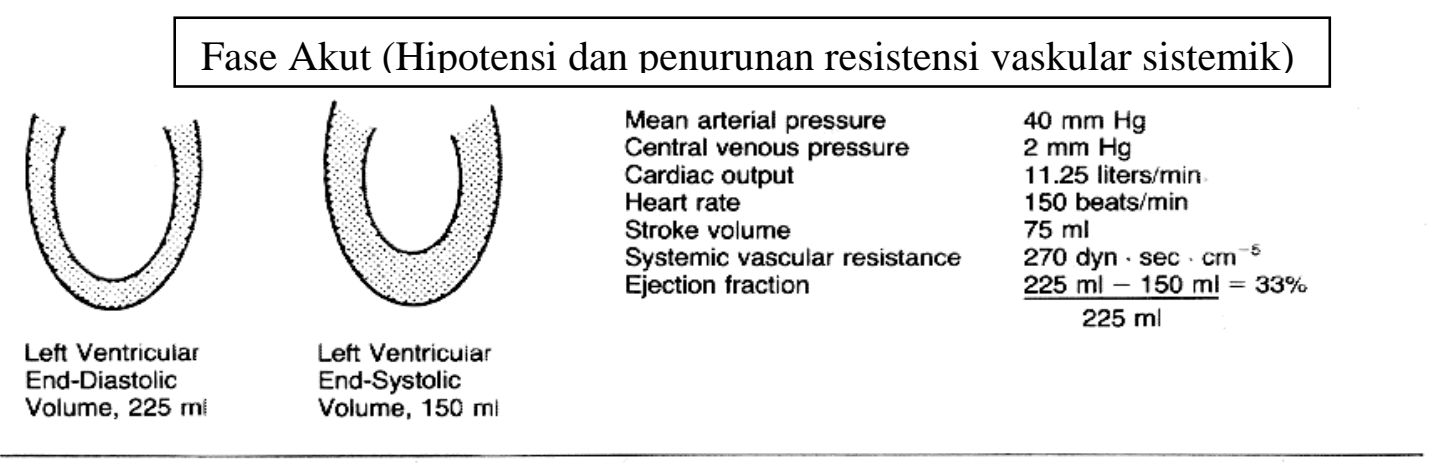

Recovery Phase (Normotension)
Mean arterial pressure
Central venous pressure

Gambar 4. Diagram skematik perubahan kerja jantung selama fase akut dan fase pemulihan syok septik pada manusia. Sumber: Braunwald E, $2005 .^{8}$

\section{ETIOLOGI DISFUNGSI MIOKARD PADA SEPSIS DAN SYOK SEPTIK}

\section{Perfusi koroner dan metabolisme}

Teori awal depresi miokard pada sepsis berdasarkan hipotesis keterlibatan iskemi miokard secara menyeluruh. Dalam kondisi normal, aliran darah arteri koroner diregulasi melewati jarak yang lebar saat aktivitas jantung. Hal ini berbeda pada pasien dengan syok penyebab lain, pasien sepsis memiliki aliran darah koroner yang tinggi dan berkurangnya perbedaan oksigen arteri koroner-sinus koronarius, sama dengan perubahan pada sirkulasi perifer. Perubahan ini disebabkan gangguan aliran pada mekanisme autoregulasi normal dan gangguan penggunaan oksigen. Bukti klinik menunjukkan mekanisme keduanya terjadi pada sepsis. Sampling studi aliran darah sinus koronarius pasien syok septik juga membuktikan perubahan pada mekanisme jantung. Peningkatan ekstraksi laktat, penurunan ekstraksi asam lemak bebas (free fatty acid = FFA) miokard dan penurunan pengambilan glukosa miokard (lebih rendah pada pasien yang tidak selamat) telah di uji coba dibandingkan dengan kontrol normal. ${ }^{7,21,28}$

\section{Radikal bebas dan disfungsi miokard}

Pada kondisi fisiologik, keberadaan sel memegang peranan penting dalam keseimbangan redoks antara fase spesies radikal bebas dan pergerakannya oleh mekanisme anti oksidan. Pada studi hewan coba, iskemi reperfusi miokard menunjukkan spesies oksigen reaktif meningkatkan diameter akhir diastolik ventrikel kiri, menurunkan kontraktilitas ventrikel kiri, dan memperburuk fungsi mitokondria. Sepsis pada hewan coba dan syok septik pada manusia menunjukkan terjadi peningkatan marker stres oksidan. Hal ini karena spesies oksigen reaktif dipengaruhi banyak faktor humoral, yang meningkat pada keadaan sepsis. Kombinasi spesies oksigen reaktif dan NO mengakibatkan terbentuknya peroksi-nitrit reaktif tinggi yang menyebabkan kerusakan membran sel dan disfungsi enzimatik serta potensial menekan fungsi mitokondria. Radikal bebas dapat menyebabkan disfungsi miokard karena hipotiroid, hipertiroid, atau luka bakar berat, tetapi bagaimana perannya dalam modulasi disfungsi miokard masih belum dapat diterangkan. ${ }^{7,21,26}$ 


\section{Peran faktor sirkulasi}

\section{Lipopolisakarida dan sitokin}

Sejumlah penelitian telah memperlihatkan jika TNF- $\alpha$ diberikan pada jaringan miokard hewan dan manusia in vitro atau ex vivo, hasilnya ialah depresi kontraktilitas yang tergantung pada konsentrasi. Penghilangan TNF- $\alpha$ pada serum pasien syok septik secara parsial mengeliminasi efek depresi miokardnya. Walaupun ujiklinik fase III yang lebih besar telah memperlihatkan tidak ada manfaat harapan hidup secara keseluruhan jika antibodi monoklonal anti-TNF- $\alpha$ diberikan pada pasien syok septik, namun fungsi ventrikel kiri membaik pada grup pasien ini. 7,11,27

Interleukin-1 $\beta$ menginduksi respons patofisiologik yang sama dengan TNF- $\alpha$. Interleukin-1 $\beta$ meningkat pada modelmodel sepsis dan syok septik manusia dan hewan. Ketika dipapar dengan IL-1 $\beta$, kontraktilitas miokard in vitro dan ex vivo terdepresi. Imunoabsorpsi IL-1 $\beta$ secara parsial menetralkan aktivitas depresan miosit jantung pada serum sepsis manusia. Pemberian antagonis IL-1 $\beta$ memperlemah manifestasi hemodinamik dan metabolik syok septik. Seperti halnya TNF- $\alpha$, mortaliti keseluruhan tidak membaik pada uji-klinik yang dirandom dengan menggunakan IL-1 $\beta .7,11,29$

Sejumlah penelitian telah memostulasikan bahwa sinergi sitokin mempunyai peran kunci pada depresi miokard sepsis. Ketika mempertimbangkan TNF- $\alpha$ dan IL$1 \beta$ secara terpisah, konsentrasi sitokin lebih tinggi diperlukan untuk mendepresi kontraktilitas miosit jantung tikus dibandingkan jika kedua sitokin ini dikombinasikan. Temuan-temuan ini telah divalidasi pada penelitian ex vivo pada trabekula atrium manusia secara tersendiri. Kombinasi TNF- $\alpha$ dan IL-1 $\beta$ menyebabkan depresi miosit pada konsentrasi 50-100 kali lebih rendah dibandingkan yang diperlukan jika diaplikasikan secara individual. Konsentrasi tersebut dalam keadaan baik di darah selama syok septik manusia. Data yang tersedia mendukung peran kausatif
TNF- $\alpha$ dan IL-1 $\beta$ yang beraksi secara sinergistik pada depresi miokard sepsis. $7,11,28$

Studi isolasi miosit jantung belakangan ini membuktikan aktivasi PMN dan miosit jantung memiliki peranan penting dalam penurunan kontraktilitas miokard. Pemberian TNF- $\alpha$ antibodi ternyata memperbaiki fungsi ventrikel kiri pada pasien syok septik. Walaupun sitokin memegang peranan penting pada awal penurunan kontraktilitas, namun masih belum dapat dijelaskan kapan terjadinya kejadian klinis, kecuali peranan sitokin dalam menginduksi ataupun melepas faktor tambahan yang menyebabkan perubahan fungsi miokard seperti prostanoids atau nitrit oksida. ${ }^{7,23,26,29}$

\section{Nitrit Oksida}

Nitrit oksida merupakan sintesis radikal bebas yang berada dimana-mana dan merupakan hasil aksi membran yang berikatan dengan nitrit oksida sintetase dari asam amino semi esensial l-arginin pada berbagai variasi ko-faktor.

Pada keadaan sepsis, jumlah besar pelepasan NO oleh induksi iNOS pada endotel vaskular dan substansi sel otot polos akan menurunkan tonus vaskular dan menimbulkan reaksi untuk menekan agen. Pada jantung dalam kondisi ini, NO akan berada dalam bentuk cGMP aksi dependen dan independen. ${ }^{7,11,29,30}$

Pada peningkatan jumlah produksi NO sebagai hasil induksi iNOS, NO akan mengikat enzim menyebabkan disfungsi sel, merangsang makrofag dan menghancurkan neutrofil, serta menghambat fungsi mitokondria, baik secara langsung, atau dalam bentuk interaksi dengan radikal bebas sebagai hasil formasi peroksinitrit (ONOO-) dan selanjutnya menyebabkan kerusakan sel. Mekanisme potensial karena NO akan memodulasi kontraktilitas miokard seperti yang ditunjukkan pada Gambar 6 dan karakteristik yang mendukung NO sebagai substansi depresan miokard seperti yang ditunjukkan dalam Tabel 2. ${ }^{7,26,28,31}$ 


\section{Prostanoid}

Prostanoid merupakan keluarga besar mediator lipid dengan berbagai keadaan fisiologik dan patologik, diproduksi dari asam arakidonik lewat enzim siklooksigenase. Terdiri dari 2 jenis isoform, yaitu enzim siklo-oksigenase-1 (sebagai pembentuk) dan enzim siklo-oksigenase-2, yang menginduksi respons terhadap sejumlah stimuli termasuk lipopolisakarida dan sitokin. ${ }^{7,21,23,29}$

Pada pasien sepsis terjadi peningkatan kadar prostasiklin dan tromboksan; hal ini dihubungkan dengan peningkatan mortalitas. Peningkatan kadar prostanoid berpasangan dengan terekspresinya enzim siklo-oksigenase-2 dalam endotel, endokardial, dan sel otot polos vaskular. Walaupun peran prostanoid langsung dalam kontrol fungsi jantung belum jelas, efek tidak langsung secara potensial lewat perubahan autoregulasi koroner, aktivasi leukosit intrakoroner dan fungsi endotel telah dipikirkan. Enzim siklo-oksigenase-2 diinduksi oleh aksi lipopolisakarida dalam sel otot polos vaskular setelah periode 10 hari, dengan konsekuensi implikasi untuk peranan depresi miokard dalam sepsis. Bukti klinis menunjukkan prostanoid sebagai substansi depresi miokard potensial terdapat pada Tabel 2. ${ }^{7,21,23,29}$

Tabel 2. Potensial faktor miokard depresan (MDS) ${ }^{3}$

Substansi $\quad$ Faktor-faktor pendukung MDS

LPS Menyerupai syok septik pada hewan dan (lipopolisakarida) manusia.

Kadarnya berhubungan dengan derajat depresi miokard.

Sitokin (TNF- $\alpha$, Sesuai karakteristik kimiawi MDS yang IL-1 $\beta$ )

Prostanoid

NO

(Nitrit Oksida)

\section{meningkat pada waktu sepsis}

Injeksi menyebabkan syok septik dengan depresi miokard dalam waktu 1 jam.

Penurunan tergantung konsentrasi pada pemendekan myosit secara in-vitro.

Antibodi meningkatkan fungsi ventrikel kiri pada manusia.

Meningkat kadarnya pada saat sepsis (berhubungan dengan induksi enzim COX 2)

COX-2 diinduksi oleh LPS dan sitokin.

Mencit yang disedasi diberikan COX-2 mempunyai efek protektif terhadap efek hemodinamik dari LPS

Bila endokard dihilangkan, maka efek kontraktilitas akan berkurang.

NO mengubah fungsi ventrikel kanan dan ventrikel kiri.

NO mengubah tonus vaskular koroner.

Injeksi LPS menginduksi iNOS dan produksi NOS yang masif.

Pada mayat, terlihat peningkatan iNOS pada jantung pasien yang sepsis.

Mekanisme jelas untuk depresi fungsi jantung.
Faktor-faktor penghambat MDS

Tidak berhubungan dengan karakteristik biokimiawi dari MDS

Tidak secara terus menerus menghambat fungsi miokard secara in-vitro (perlu kultur dengan aktivasi makrofag).

Tidak dapat diperhitungkan pada 7-10 hari dari depresi miokard pada waktu sepsis

Bukti ekuivokal untuk aktivitas depresi miokard langsung.

Produksi tergantung induksi enzim - tidak berlaku pada depresi miokard awal.

Ketidak sesuaian hasil dari inhibisi nitrat oksida sintetase.

Ekspresi iNOS tidak terlihat pada semua spesies.

Depresi miokard tidak terlihat pada semua spesies.

Kadar puncak dari NOS menurun, namun fungsi miokard tetap menurun untuk waktu yang lama.

Produksi tergantung dari induksi enzim tidak berlaku pada depresi miokard awal. 


\section{Peranan sel endotel}

Dari uji klinis sebelumnya diketahui sel endotel endokard dapat memengaruhi fungsi miokard. Hal ini menunjukkan bahwa kerusakan selektif endokard menyebabkan terjadi pemendekan segera yang ireversibel dari regangan isometrik miosit jantung terisolasi. Endokard akan memroduksi sejumlah substansi yang menyebabkan perubahan kontraktilitas miosit. Sebagai tambahan, studi-studi in vitro menunjukkan sel endotel endokard menyebabkan perubahan kontraktilitas miosit sebagai respons dari sejumlah faktor, termasuk asetilkolin, vasopresin, endotelin, dan penilefrin. Sel endotel vaskular koroner memiliki persamaan secara histo-fisiologik dengan sel endokard dan memengaruhi performa kontraksi miosit jantung yang berdekatan. Pada keadaan sepsis sel endotel endokard maupun sel endotel vaskular akan menghasilkan substansi yang merubah tonus vaskular, sehingga menyebabkan hiporeaktivitas untuk menekan agen penyebab sepsis dan menekan kontraksi miosit. Substansi lain yang dihasilkan neutrofil akan mengaktivasi respons inflamasi lokal, fase spesies oksigen reaktif, serta kerusakan endokard itu sendiri. Kerja enzim yang diinduksi seperti enzim siklo-oksigenase- 2 dan iNOS akan menghasilkan produk modulator tonus vaskular dan kontraktilitas miosit. ${ }^{7,21,26,29}$

\section{MANIFESTASI KLINIK DISFUNGSI MIOKARD PADA SEPSIS DAN SYOK SEPTIK}

Efek syok septik yang tersering pada sistem kardiovaskular ialah karakteristik terhadap profil hemodinamik berupa peningkatan indeks jantung (cardiac index) dan penurunan resistensi vaskular sistemik. Studi pendahuluan pada pasien yang mengalami syok septik melaporkan terjadi penurunan indeks jantung. Pasien-pasien tersebut memiliki preload ventrikel yang tidak adekuat, dan yang digunakan untuk mengukur volume status pada saat itu ialah tekanan vena sentral (central venous pressure $=\mathrm{CVP}$ ). Pada studi belakangan ini diketahui bahwa tekanan vena sentral tidak memiliki hubungan dengan tekanan baji kapiler paru (pulmonary capillary wedge pressure $=$ PCWP) atau tekanan atrium kiri, yang ternyata lebih akurat dalam pengukuran tekanan preload ventrikel kiri. Depresi miokard yang reversibel merupakan manifestasi dilatasi ventrikel dan penurunan fraksi ejeksi. Hal ini dibuktikan pada studi hewan coba dimana didapati iskemi miokard sebagai akibat tidak adekuatnya aliran darah koroner. Hal ini dibuktikan oleh Cunnion et al yang melakukan pengecekan aliran darah koroner pada miokard yang terdepresi dengan menggunakan termodilusi kateter sinus koronarius untuk mengukur aliran darah koroner dan miokard yang terdepresi. ${ }^{7,21,30}$ Pada penelitian terhadap kontraktilitas miokard pasien sepsis didapatkan penurunan fraksi ejeksi kedua ventrikel (Left ventricular ejection fraction/LVEF dan Right ventricular ejection fraction/ RVEF) (Tabel 3). ${ }^{29}$

Tabel 3. Variabel hemodinamik pada pasien yang selamat dan yang meninggal akibat syok septik $^{9}$

\begin{tabular}{lcccccc}
\hline \multirow{2}{*}{ Variabel } & Awal & $\begin{array}{c}\text { Hidup } \\
\text { Akhir }\end{array}$ & $\mathrm{P} \gamma$ & Awal & Akhir & $\mathrm{P} \gamma$ \\
\hline $\begin{array}{l}\text { Fraksi } \\
\text { ejeksi }\end{array}$ & 31 & 47 & 0,001 & 40 & 43 & $\mathrm{NS}$ \\
$\begin{array}{l}\text { ventrikel } \\
\text { kiri (\%) }\end{array}$ & & & & & & \\
$\begin{array}{l}\text { LVEDVI } \\
\left(\mathrm{ml} / \mathrm{m}^{2}\right)\end{array}$ & 145 & 106 & 0,012 & 124 & 102 & $\mathrm{NS}$ \\
$\begin{array}{l}\text { Fraksi } \\
\text { ejeksi } \\
\text { ventrikel }\end{array}$ & 35 & 51 & 0,001 & 41 & 39 & $\mathrm{NS}$ \\
$\begin{array}{l}\text { kanan } \\
(\%)\end{array}$ & & & & & & \\
$\begin{array}{l}\text { RVEDVI } \\
\left(\mathrm{ml} / \mathrm{m}^{2}\right)\end{array}$ & 124 & 88 & 0,031 & 20 & 114 & $\mathrm{NS}$ \\
\hline
\end{tabular}

$\gamma$ : paired sample t-Test; LVEDVI: Left ventricular end diastolic index; RVEDVI: Right ventricle end diastolic index

Penurunan fraksi ejeksi disertai kompensasi peningkatan denyut jantung dan peningkatan volume ventrikel (LVEDV dan RVDV) melalui dilatasi 
miokard dibutuhkan untuk mempertahankan curah jantung yang cukup. Penurunan fraksi ejeksi dan peningkatan volume diastolik akhir serta volume sistolik akhir sudah tampak dalam 24 jam pertama dan kembali mendekati normal pada hari ke 7 sampai 10 dari onset. ${ }^{9}$ Penurunan fraksi ejeksi dan terjadinya dilatasi ventrikel yang reversibel (Gambar 3) merupakan perubahan tampilan jantung khas pada pasien sepsis yang selamat. ${ }^{9,23,25}$ Ventrikel yang tidak mampu berdilatasi berhubungan dengan mortalitas yang lebih tinggi. $^{9}$ Respons terhadap pemberian infus berbeda antara kontrol (pasien sakit berat bukan sepsis), sepsis tanpa syok. dan syok septik. $^{23}$ Kurva Frank-Starling hubungan left ventricle stroke work index (LVSWI) dengan end diastolic volume index (EDVI) ternyata bergeser ke kanan dan ke bawah (Gambar 5).

Pada Gambar 5 didapatkan LVSWI awal lebih rendah dengan volume ventrikel lebih banyak dibanding kontrol. Respons peningkatan LVSWI pada pemberian cairan juga lebih rendah. Hal tersebut membuktikan penurunan penampilan ventrikel pada sepsis dan syok septik. ${ }^{6,9,21,31}$
Penyebab pasti terjadinya penurunan fraksi ejeksi ini belum jelas benar. Parillo et $\mathrm{al}^{9}$ membuktikan bahwa substansi yang bersirkulasi menurunkan kontraktilitas miokard in vitro, dan depresi sel-sel miokard in vitro berkorelasi dengan depresi fraksi ejeksi in vivo. Substansi yang dapat menekan miokard disebut sebagai Myocardial Depressant Substances (MDS). Reilly $^{27,28}$ menyatakan bahwa MDS merupakan molekul dengan ukuran menengah, dengan berat $10.000 \mathrm{~d}$, larut dalam air, dan tidak melalui membran dialisis. ${ }^{6,9,21,32}$ Beberapa mediator yang terlibat dalam syok septik seperti TNF- $\alpha$, IL-1, dan anafilatoksin mempunyai aktivitas menekan kontraktilitas miokard. Pada penelitian dengan IL-1, IL-2, dan endotoksin tidak menunjukkan depresi kontraksi miosit. TNF- $\alpha$ dengan dosis 250 unit/ml mengakibatkan penurunan pemendekan miosit yang bermakna. ${ }^{9,21,28,31,33}$

Penelitian endotoksin pada manusia dengan pemantauan melalui kateter arteri pulmonal mendapatkan peningkatan indeks jantung dan detak jantung serta penurunan tahanan pembuluh darah sistemik dibanding kontrol pada jam ke 3.,19

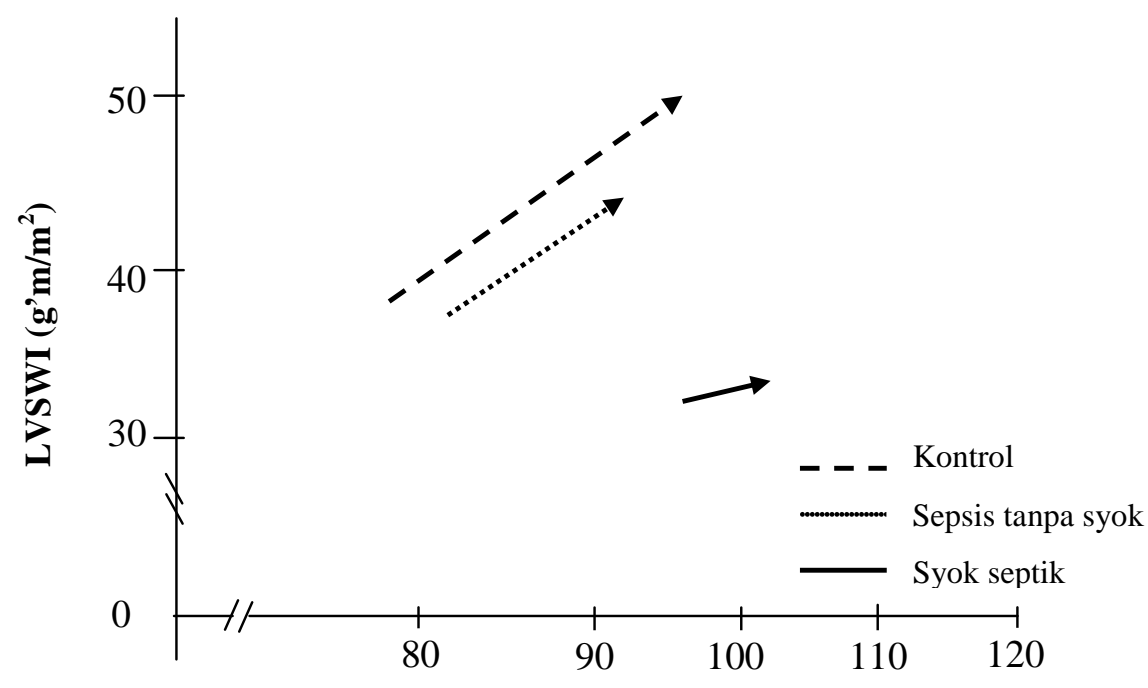

Gambar 5. Hubungan Frank-Starling untuk setiap grup pasien Data mewakili nilai rata-rata sebelum dan sesudah infus dari EDVI dan LVSWI untuk setiap grup. Sumber: Deymann A et al, $2002 .^{6}$ 
LVEF menurun di bawah garis awal dan di bawah kontrol pada jam ke-5 dan ke-6 setelah pemberian endotoksin sedangkan EDVI dan ESVI meningkat. Penampilan jantung dinilai dengan perbandingan puncak tekanan sistolik (peak systolic pressure/psp) dengan ESVI pada saat awal dan setelah pemberian cairan, dan didapatkan perubahan rasio yang abnormal pada penerima endoktosin. Data ini menunjukkan penurunan penampilan sistolik selama pemberian endotoksin dan terlepasnya pengaruh beban awal dan beban akhir; selanjutnya rasio penurunan tekanan ventrikel kiri terhadap volume juga menurun dan hal ini menunjukkan peningkatan regangan ventrikel. Pasien dengan volume intravaskular sangat kurang dapat mempunyai curah jantung rendah dengan tahanan sistemik yang tinggi. Hipovolemia diperberat dengan kehilangan cairan yang tak terlihat (insensible loss) disebabkan hipertermi, venodilatasi, dan transudasi cairan keluar ruangan intravaskular melalui peningkatan permeabilitas kapiler. $^{3}$ Curah jantung yang rendah dijumpai pada pasien dengan disfungsi jantung sebelumnya dan hal itu berhubungan dengan kondisi yang lebih buruk. 3,18,23,34

\section{SIMPULAN}

1. Disfungsi miokard merupakan variabel penting pada sepsis dan syok septik.

2. Perubahan kardiovaskular pada sepsis didasari oleh proses yang kompleks.

3. MDS yang beredar memberi gambaran sitokin yang berbeda, mencakup TNF$\alpha$ dan IL-1 $\beta$ yang beraksi secara sinergis. Efek depresan miokard dari sitokinsitokin ini sebagian diperantarai melalui mekanisme produksi NO.

4. Perubahan utama kardiovaskular pada sepsis ialah vasodilatasi arteri, peningkatan curah jantung, penurunan kontraktilitas miokard, peningkatan volume ventrikel dan perubahan respons ventrikel terhadap perangsangan simpatis serta pemberian cairan.

5. Gangguan fungsi jantung pada sepsis diakibatkan oleh kombinasi disfungsi sistolik dan diastolik.

6. Perubahan kardiovaskular pada pasien sepsis yang selamat bersifat reversibel.

7. Standar terapi dewasa ini untuk pasien syok septik masih diarahkan pada pemantapan. kembali organ dan perfusi jaringan serta pemberian oksigen melalui resusitasi cairan dan dukungan inotropik. Penelitian yang sedang berlangsung ditujukan untuk memahami mekanisme seluler disfungsi jantung yang memberi alternatif pilihan terapeutik baru yang menarik.

\section{DAFTAR PUSTAKA}

1. Kaukonen K-M, Bailey M, Suzuki S, Pilcher D, Bellomo R. Mortality related to severe sepsis and septic shock among critically ill patients in Australia and New Zealand, 2000-2012. JAMA. 2014;311(13):1308-16.

2. Fernandes JC Jr, Akamine N, Knobel E. Myocardial depression in sepsis. SHOCK. 2008;30(suppl.7);14-7.

3. Dellinger RP, Levy MM, Rhodes A, Annane D, Gerlach H, Opal SM, et al. Surviving sepsis campaign: International guidelines for management of severe sepsis and septic shock: 2012. Critical Care Medicine. 2013;41(2):580-637.

4. Danai P, Martin GS. Epidemiology of sepsis: recent advances. Curr Infect Dis Rep. 2005; 7(5):329-34.

5. Brierley J, Carcillo JA, Choong K, Cornell T, DeCaen A, et al. Clinical practice parameters for hemodynamic support of pediatric and neonatal septic shock: 2007 update from the American College of Critical Care Medicine. Crit Care Med. 2009;37(2):666-88.

6. Deymann A, Court O, Kumar A, Parrillo JE, Kumar A. Clinical review: Myocardial depression in sepsis and septic shock. Crit Care Med. 2002;6:500-8.

7. Hollenberg SM, Ahrens TS, Annane D, Astiz ME, Chalfin DB. Practice parameters for hemodynamic support of sepsis in adult patients: 2004 update. Crit Care Med. 2004;32:1928-48.

8. Braunwald E. Assesment of cardiac 
function. In: Braunwald E, editor. Heart Disease. A Text Book of Cardiovaskular Medicine Vol. 1 (7th ed). Philadelphia: WB Saunders, 2005; p. 459-83.

9. Kontra JM. Evidence-based management of severe sepsis and septic shock. The Journal of Lancaster General Hospital. 2006;1(2):39-46.

10. Vallet B. Bench-to-bedside review: Endotelial cell dysfunction in severe sepsis: a role in organ dysfunction. Crit Care Med. 2003;7:130-8.

11. Wong J, Kumar A. Myocardial depression in sepsis and septic shock. Sepsis. New York: Springer, 2006; pp. 55-73. DOI 10.1007/0-387-345744_6

12. Guisset O, Dilhuydy MS, Thiébaut R, Lefèvre J, Camou F, Sarrat A, et al. Decrease in circulating dendritic cells predicts fatal outcome in septic shock. Intensive Care Med. 2007; 33(1):148-52.

13. Baron VA, Prin S, Chergui $K$. Hemodynamic instability in sepsis in bedside assessment by doppler echocardiography. Am J Respir Crit Care Med. 2003;168:1270-6.

14. Morrell R, Micek ST, Kollef MH. The Management of severe sepsis and septic shock. Infect Dis Clin N Am. 2009;23:485-501.

15. Vincent JL, Sakr Y, Sprung CL, Ranieri VM, Reinhart K, Gerlach $\mathbf{H}$, et al. Sepsis in European intensive care units: results of the SOAP study. Crit Care Med. 2006;34(2):344-53.

16. Hoffmann JN, Vollmar B, Laschke MW, Fertmann JM, Jauch KW. Microcirculatory alterations in ischemia-reperfusion injury and Sepsis. Crit Care Shock. 2005;9:33-47.

17. Vincent JL, Backer DD. Microvaskular dysfunction as a cause of organ dysfunction in severe sepsis. Crit Care Shock. 2005;9:9-12.

18. Koch T, Geiger S, Ragaller MJ. Monitoring of organ dysfunction in sepsis/systemic inflammatory response syndrome: Novel Strategies. J Am Soc Nephrol. 2001;12:53-60.

19. Belcher E, Mitchell J, Evans T. Myocardial dysfunction in sepsis: No role for No? Heart. 2002;87:507-9.
20. Amersfoort ASV, Van Berkel TJC, Kuiper J. Receptors, mediators, and mechanisms involved in bacterial sepsis and septic shock. Clin Micr Rew. 2003;16:379-414.

21. Dhainaut JF. Re-establishing organ function in severe sepsis: targeting the microcirculation. Crit Care Shock. 2005;9:1-2.

22. Greg SM. Sepsis, severe sepsis and septic shock: changes in incidence, pathogens and outcomes. Expert Rev Anti Infect Ther. 2012;10(6):701-6.

23. Young JD. The heart and circulation in severe sepsis. $\mathrm{Br} \mathrm{J}$ Anaesth. 2004;93:114-20.

24. Hotchkiss RS, Karl IE. The pathophysiology and treatment of sepsis. N Engl J Med. 2003; 348:138-50.

25. Levy SB. The antibiotic paradox: How the misuse of antibiotics destroys. N Engl J Med. 2002; 347:1213-6.

26. Landry JW, Oliver DA. The pathogenesis of vasodilatory shock. N Engl J Med. 2001; 345:588-95.

27. Mebazaa A, Tavernier J, Benoit C, Callebert J. Heart dysfunction in human septic shock. Clin Pulm Med. 2002;9:206-12.

28. Parlillo JE. Septic shock in humans: Clinical evaluation, pathogenesis and therapeutic approach. In: Shoemaker WC, Thomson WL, Halbrook PR, editors. Textbook of Critical Care $\left(4^{\text {nd }}\right.$ ed). Philadelphia: WB Saunders, 1999; p. 1016-44.

29. Derek CA, Tom van der $P$. Severe sepsis and septic shock. N Engl J Med. 2013;369:840-51.

30. Azevedo LCP, Park M, Schettino GPP. Novel potential therapies for septic shock. SHOCK. 2008;30 (suppl. 7):60-6.

31. Aziz M, Jacob A, Wang P. Revisiting caspases in sepsis. Cell Death \& Disease. 2014;5:e1526.

32. Kumar A, Schupp E, Bunnell E, Ali A, Milcarek B, Parrillo JE. Cardiovascular response to dobutamine stress predicts outcome in severe sepsis and septic shock. Crit Care. 2008;12(2):R35.

$\begin{array}{llr}\text { 33. Landesberg } & \text { G, Gilon } & \text { D, Meroz } \\ \text { Y, Georgieva } & \begin{array}{r}\text { M, Levin } \\ \text { PD, } \\ \text { Goodman, }\end{array} \text { et } \text { al. } & \text { Diastolic }\end{array}$


22 Jurnal Biomedik (JBM), Volume 7, Nomor 1, Maret 2015, hlm. 8-22

dysfunction and mortality in severe sepsis and septic shock. Eur Heart J. 2012;33(7):895-903.
34. Danai PA, Sinha S, Moss M, Haber MJ, Martin GS. Seasonal variation in the epidemiology of sepsis. Crit Care Med. 2007;35(2):410-5. 